\title{
REAL TIME POWER SWING MONITORING IN A HYDRO POWER PLANT SUPPORTED BY SYNCHRONIZED MEASUREMENTS
}

\author{
Niksa Vrkic, Srdjan Skok, Vedran Kirincic
}

Preliminary notes

Dynamic disturbances in the electric power system exert influence on the operation of generators and cause several other disturbances, such as a power swing, resulting in the activation of protections, the stalling of generators and their disconnection from the grid. The application of synchronized measurements in the field of power swing has mainly been focused on a transmission power system and on the loss of synchronism on power lines. In this paper the original solution for real time power swing monitoring in a hydro power plant based on synchronized phasor measurements and Prony analysis is proposed, which is a basis for mitigation of disturbances. Prony analysis is used for the analysis of frequency, decreasing or increasing amplitude of oscillations based on the synchronized measurements of voltage phasors. Using the synchronized phasors measurements for power swing monitoring allows detection and monitoring of power swings in real time, which was not possible with classical methods. To conclude with, the results of the implemented real time monitoring system in the real hydro power plant are given in the paper.

Keywords: hydro power plant; power swing; Prony analysis; synchronized measurements; system stability

Nadzor njihanja snage hidroelektrane u stvarnom vremenu podržan sinkroniziranim mjerenjima

Prethodno priopćenje

Dinamički poremećaji u elektroenergetskom sustavu odražavaju se na rad generatora i uzrokuju niz poremećaja od kojih je značajno njihanje snage, koje može dovesti do prorada zaštita, ispada generatora iz pogona i odvajanja od mreže. Dosadašnja primjena sinkroniziranih mjerenja u području njihanja snage uglavnom se odnosila na prijenosni sustav te gubitak sinkronizma na dalekovodu. U ovom radu prikazano je izvorno rješenje za nadzor njihanja snage u hidroelektrani u stvarnom vremenu zasnovano na sinkroniziranim mjerenjima i Prony analizi, koja je osnova za ublažavanje poremećaja. Prony analiza je korištena za analizu frekvencije, prigušenja ili raspirivanja i amplitudu njihanja snage na osnovu sinkroniziranih mjerenih vrijednosti fazora napona. Uvođenjem sinkroniziranih mjerenja u nadzor njihanja snage omogućava se detekcija i nadzor njihanja snage u stvarnom vremenu, što klasičnim metodama nije bilo moguće. Zaključno, u radu su prikazani rezultati implementiranog nadzora njihanja snage u stvarnom vremenu na primjeru stvarne hidroelektrane.

Ključne riječi: hidroelektrana; njihanje snage; Prony analiza; sinkronizirana mjerenja; stabilnost sustava

\section{Introduction}

Active power swings in electric power systems occur due to the interaction of the generator rotor with the rest of the electric power system. Generators react at sudden changes in the system, such as near short circuits, the sudden changes of load and the changes of power flows. A power swing is actually the consequence of the alternating component of torsion torque on generator terminals, which causes torsion vibrations of the rotor.

The traditional methods of power swing detection in the transmission power system are based on local measurements integrated in the protections of transmission lines. The synchronized measurement technology enables power swing monitoring and detection in real time [1] $\div[5]$, which was not the case before. The power swing detection in the transmission power system is used for the mitigation of the non-selective operation of a distant protection as well as the initialisation of alarms in control centres. In the case of the increasing amplitude of oscillations, the protection against the loss of synchronism is usually used.

Power swing detection in the transmission power system is a function that indicates amplitudes, frequencies and the level of damping of oscillations in the power system (local mode and inter-area mode oscillations) by using various computing methods, such as modal analysis, Fourier analysis and Prony analysis. The outputs of this function can be used in the transmission power system as a part of control functions [1], [4]. The continuous monitoring of voltage phase angles in the transmission power system enables the detection of sudden change of angle [6]. Based on synchronized phasor measurements, the loss of synchronism can be detected in real time and activities for mitigation of the occurred state can be taken [7]:[9].

Electromechanical oscillations are of the following types: interplant mode oscillations, local plant mode oscillations, inter-area mode oscillations, control mode oscillations and tensional modes between rotating plants. The literature review reveals that the power swing detection and monitoring based on the synchronized measurements of voltages were applied in the transmission power systems and phenomena grouped under power system small signal stability were monitored. Especially were observed the phenomena of inter-area mode oscillations and the loss of synchronism $[10] \div[14]$.

In this paper, the solution of real time power swing monitoring in a hydro power plant based on the synchronized phasor measurements is proposed. The point of monitoring is the hydro power plant and the generator that swings against the surrounding power system is monitored, usually with the frequency of $1,0 \div$ 3,0 Hz. Real time Prony analysis is used for the analysis of frequency, decrease or increase of the amplitude of swings in the hydro power plant. The power swing monitoring in the hydro power plant is of local character and it is used for the protection of the hydro power plant as well as for post-mortem analyses so as to tune up parameters, such as a Power System Stabilizer (PSS). The proposed solution can be the integral part of system protections, known as Wide Area Monitoring, Protection 
and Control (WAMPAC) or System Integrity Protection Schemes (SIPS) that are used for the mitigation of disturbances in the power system around the hydro power plant, which caused power swings in the hydro power plant.

\section{Prony analysis}

For the completeness of the paper, a brief overview of Prony analysis is given, while a more elaborate explanation can be found in [15].The signal $f(t)$ that is uniformly sampled with $N$ samples is represented as a series of damped complex exponentials:

$$
\begin{aligned}
& \hat{f}(t)=\sum_{i=1}^{N} A_{i} e^{\sigma_{i} t} \cos \left(2 \Pi f_{i} t+\phi_{i}\right) \\
& \hat{f}(t)=\sum_{i=1}^{N} \frac{1}{2} A_{i} e^{ \pm j \phi_{i}} e^{\lambda_{i} t}
\end{aligned}
$$

where $\lambda_{i}=\sigma_{i} \pm j \omega_{i}$ are the eigenvalues, while $\sigma_{i}, \phi_{i}, f_{i}$ and $A_{i}$ are the damping components, the phase components, the frequency components and the amplitude components of the series, respectively.

If the sampling period $T$ is introduced, where $t=k T$, it follows:

$$
\hat{f}(k T)=\sum_{i=1}^{N} B_{i} z_{i}^{k}
$$

where $B_{i}=\frac{1}{2} A_{i} e^{j \phi_{i}}$ and $z_{i}=e^{\left(\sigma_{i}+j 2 \Pi f_{i}\right) T}$. The damping $\alpha_{i}$, frequency $f_{i}$, amplitude $A_{i}$ and phase angle $\theta_{i}$ of $i$-th component can be determined as given in Tab. 1 .

Table 1 The damping, frequency, amplitude and phase angle of $i^{\text {th }}$ component in Prony analysis

\begin{tabular}{|l|c|}
\hline Damping & $\alpha_{i}=\frac{\ln \left|z_{i}\right|}{T}$ \\
\hline Frequency & $f_{i}=\frac{\tan ^{-1} \mid \frac{\operatorname{im}\left(z_{i}\right) \mid}{\operatorname{re}\left(z_{i}\right) \mid}}{2 \prod T}$ \\
\hline Amplitude & $A_{i}=\left|B_{i}\right|$ \\
\hline Phase angle & $\theta_{i}=\tan ^{-1} \mid \frac{\operatorname{im}\left(B_{i}\right) \mid}{r e\left(B_{i}\right) \mid}$ \\
\hline
\end{tabular}

The application for the voltage phase angles monitoring in the power system provides real time information about the loading level of the monitored corridor or the transmission line. The calculation for real time phase angles monitoring continually calculates and a graphical interface visualizes the difference between voltage phase angles of any two nodes in the system with deployed Phasor Measurement Units (PMUs). The calculation of the difference between voltage phase angles can be assigned to any transmission line or corridor in the monitoring system. In the case that the difference between voltage phase angles overreaches a predefined threshold, the algorithm warns the user. The access to historical data is enabled through a historical basis for analysis and interpretation of past scenarios and events. The differences between voltage phase angles are archived with time resolution of $20 \mathrm{~ms}$. The accuracy of visualisation of the voltage (current) phase angles differences cannot be lower than $\pm 0,1^{\circ}$. Input signals for the calculation of voltage phase angle differences are absolute phase angles from the synchronized phasor measurements of voltages and currents.

The input signal in Prony analysis is active power on the transmission line and it is necessary to calculate frequency and the damping of the dominant oscillatory mode on that transmission line. It is necessary that the calculation processes the input signal of active power by detecting the values of dominant modes of oscillations (as the dominant mode of oscillations it is assumed the one with the lowest damping).It is necessary that the calculation visualizes the frequency and the damping of swings in real time.

\section{Power swing monitoring in hydro power plants 3.1 Hardware scheme}

The proposed solution for power swing monitoring in hydro power plants (PSMHYD) is based on the deployment of at least (depending on the power swing problem) two PMUs; one at the generator bus, at the higher voltage side and another at the side of the transmission system, as given in Fig. 1.

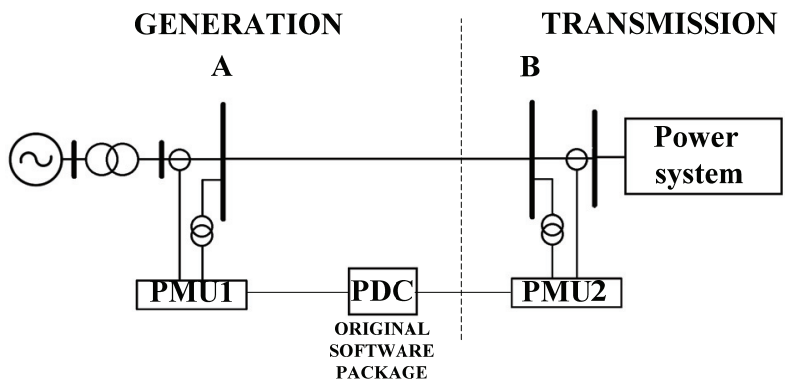

Figure 1Hardware scheme for power swing monitoring in generating facilities

It is necessary to ensure the optical link between two PMUs and the Phasor Data Concentrator (PDC) that is deployed in the hydro power plant. The PDC should process acquired information as it is described in the sequel.

\subsection{Phasor data concentrator with software scheme}

This section provides the proposal of the monitoring system architecture. The software package runs on the PDC that is deployed at the generating facility. The functionality of the system needs to be distributed over components that mutually communicate as it is required in global requests so that the functionality can be redistributed amongst several servers in the case of the increased loading of the server. The system needs to contain the service for data acquisition, distribution and processing; the database for saving system parameters; a network model as well as measured and calculated data; the system for calculation and the clients with graphical 
interfaces for data administration and visualisation. The system needs to support data acquisition in real time from external sources and it has to allow sending data in real time towards external recipients. The system needs to contain at least the components described in the sequel. The schematic overview of the system architecture is given in Fig. 2.

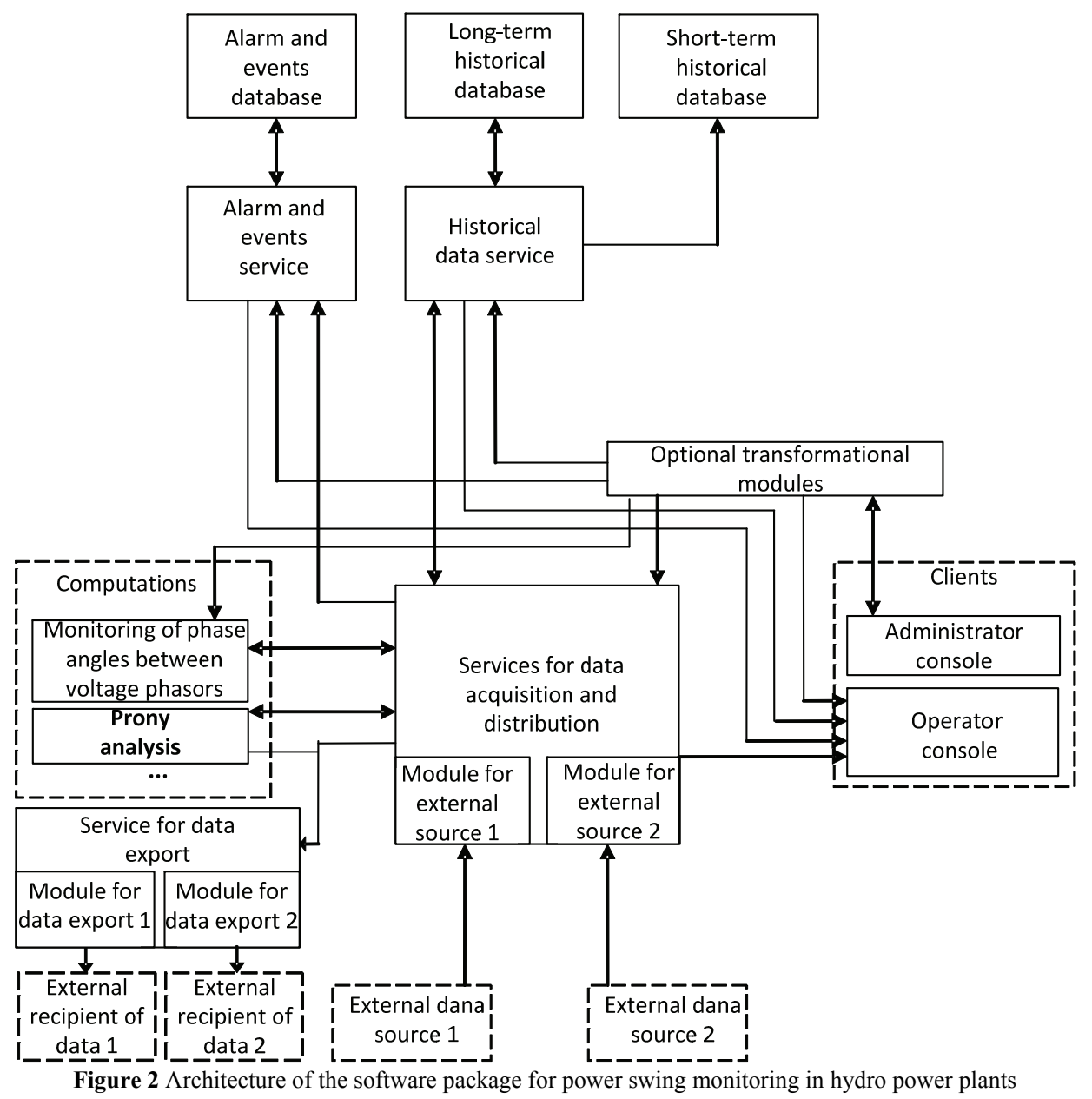

Transformational modules: the access of other system components to the central system model database can be either direct or through transformational modules that are used to adapt the abstract data structure into the form that is more appropriate for processing in the given components of the system.

The service for data acquisition and distribution: the acquisition of measured values from external data sources as well as distribution of these data towards other parts of the system is done through the central service for data acquisition and distribution. The service has to allow the reception of data in real time with different time resolutions depending on possibilities of data sources. All the received data need to be time synchronized.

The service for data export: data export in real time needs to be done though a special service that collects measured and computed data through the service for data acquisition and distribution. The service needs to allow data sending towards arbitrary number of external recipients under the condition that for each recipient a special set of data can be determined.

The service for alarms and events: important events in the system need to be identified and archived by the service for alarms and events. The definitions of alarms and events, in which the parameters that determine range of measured and computed values are included, need to be archived in the central system model database.

The alarms and events database: alarms and events that are identified by the service for alarms and events need to be archived in the alarms and events database. It needs to be allowed the option that users can afterwards gain an overview of the data stored in this database through a graphical interface.

The historical data service: there has to exist the possibility of saving every measured and computed value in the system for later use. Furthermore, there has to be the option of determining which values are saved and for how long. The historical data service has to save all the data selected for archiving for later analysis, visualisation, export into a file or replay functions. The service saves data into two historical databases: long-term and shortterm.

Administrator console: for a system administrator there has to be a special application with a graphical interface through which all system parts could be configured and all the data necessary for correct operation of the system could be inserted.

Operator console: for users other than the administrator there has to be a special application that would allow the graphical overview of data in real time as 
well as the historical data, the export of data in a file, the functions for data analysis, reporting users about alarms and events in the system, etc.

\section{$4 \quad$ PSMHYD applied on the real hydro power plant}

The problem of the power swings on both machines in the hydro power plant Dubrava in Croatia has existed since the machines have been commissioned. The power swing increases with the active power of machines, it reaches the level of $0.5 \mathrm{MW}$ and it always occurs with the rotational frequency of $2.083 \mathrm{~Hz}$. With the respect of permanent swings, the power swings can significantly increase in the case of additional disturbance on the turbine rotor. In these situations, in most cases the increase of swing amplitudes can be eliminated only by stopping and restarting the machines (there are up to 10 such cases on each machine annually).

This phenomenon has been investigated by many renowned institutions (from turbines and generators manufactures over several institutions and faculties) during the last 20 years. In order to identify the cause of power swings the measurements of hydro dynamic phenomena, the measurements of electric parameters of generators, the measurements on the excitation system and the voltage regulator were carried out. The obtained results indicated that the part of the machine that has dominantly been investigated (turbine or generator) does not show irregularities that might be responsible for the power swings. The last studious testing was carried out in 2004 when it was concluded that it is about a resonant phenomenon. The results of measurements and computer analysis indicated that under the full active power (with the reactive power about zero), the own frequency of the machine becomes closer to the rotational frequency so that the machine is practically in the state of electromechanical resonance.

The own frequency of the machine is computed from a synchronizing moment (rigidity of a magnetic field) and a mechanical time constant, i.e. a moment of inertia. In order to determine the synchronizing moment except for the basic parameters of the generator $\left(X_{d}\right.$ and $\left.X_{q}\right)$, it is necessary to know the load angle $(\delta)$, the fictive induced voltage $\left(E_{o}\right)$, which is proportional to the excitation current, and the generator voltage.

In the monitoring system, the load angle is computed as the angle between a rotor position and a generator voltage. In order to gain a more realistic overview, the load angle should be determined according to the voltage of a "stiff" network, the equivalent external reactance and the voltage of the stiff network. Therefore, it is extremely important to know the stiff network voltage phasor in order to analyse the power swing phenomenon.

In 2007, there were PSSs implemented on the machines in the hydro power plant Dubrava, with big expectations regarding the possibility of affecting power swings. The implemented PSSs (type 28) did actually increase power swings to a certain extent, but after the appearance of the mechanical torque, no effect of the PSSs was confirmed up to the present moment. The measurement of the network voltage phasor should provide a better insight into the functionality of the PSSs.

The solution applied to the given problem includes the deployment of several PMUs. One PMU was deployed at the generator bus in the hydro power plant Dubrava, while other units were deployed at locations that are closer or farther from the hydro power plant, at different voltage levels, in order to monitor the effect of the location of disturbance from the rest of the power system on the power swings in the hydro power plant Dubrava. In Fig. 3 and Fig. 4 the locations and the schematic overview of the deployed PMUs are given.

After the power swing monitoring system based on synchronized phasor measurements was established, the synchronized phasor measurements from the observed locations were transferred towards the PDC where they were processed. Prony analysis was used to analyse several events. Due to limited space, only two operating events are presented:

1) The event that occurred on $30^{\text {th }}$ August 2012 at $02: 51$ AM: the switching of the transformer for the hydro power plant load in the hydro power plant Dubrava, which can be characterised as a close disturbance. The active power swing monitored is given in Fig. 5 in green line.

2) The event that occurred on $24^{\text {th }}$ July 2012 at 1:50 PM: an outage of the transformer in the transformer station Ludbreg, which can be characterised as a farther disturbance, since the distance between the transformer station Ludbreg and the hydro power plant Dubrava is about $20 \mathrm{~km}$. The active power swing monitored is given in Fig. 6 in green line.

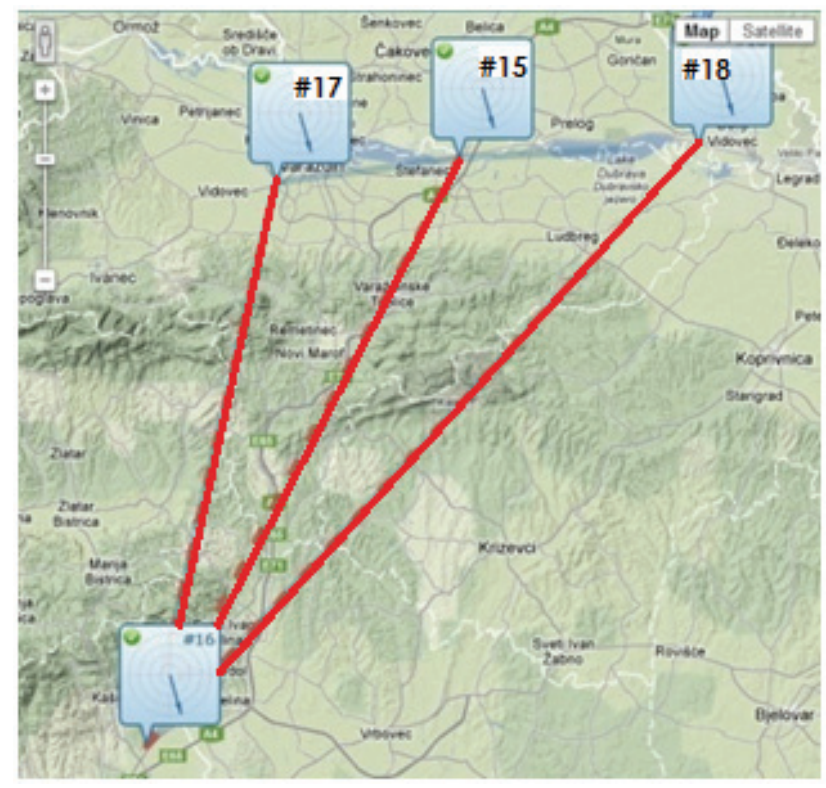

Figure 3 Locations of the deployed PMUs

It is important to emphasize that the focus of this paper is not the cause of power swings in the hydro power plant or the solution for this issue, but the description of the real time power swing monitoring system based on synchronized phasor measurements that is applied in the real hydro power plant. 


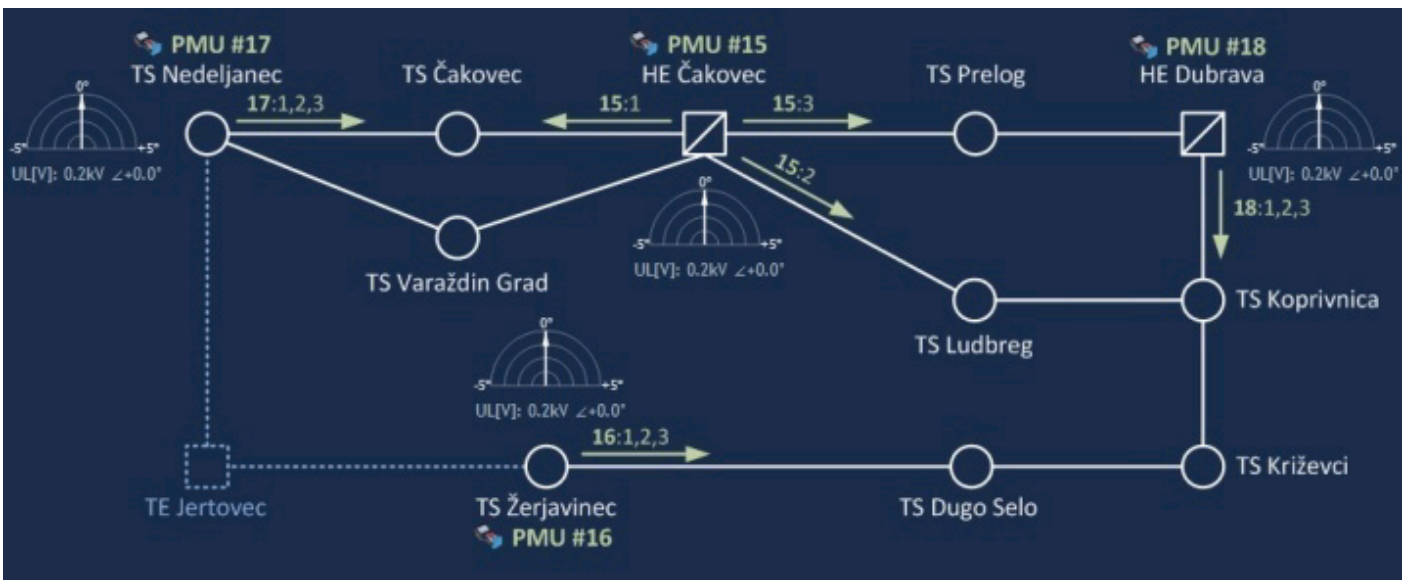

Figure 4 Schematic overview of the deployed PMUs $\begin{array}{ll}\text { Trigger no. 53: the difference between PMU\#18 Active Power Total and PMU\#18 low-pass (tau=5.0 s) of } & 8 / 30 / 2012 \\ \text { Active Power total should be 0.0 W with max abs error 3.0 MW. Event started with value -5.9 MW. } & 02: 51: 09.600\end{array}$

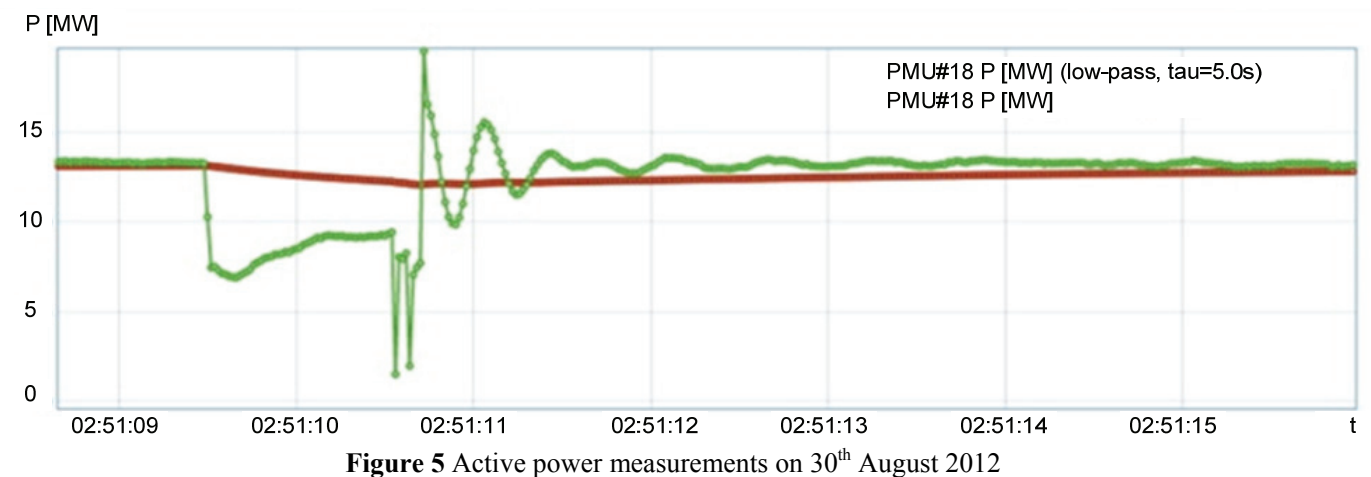

Trigger no. 53: the difference between PMU\#18 Active Power Total and PMU\#18 low-pass (tau=5.0 s) of 7/24/2012 Active Power total should be $0.0 \mathrm{~W}$ with max abs error $3.0 \mathrm{MW}$. Event started with value $-24.1 \mathrm{MW}$.

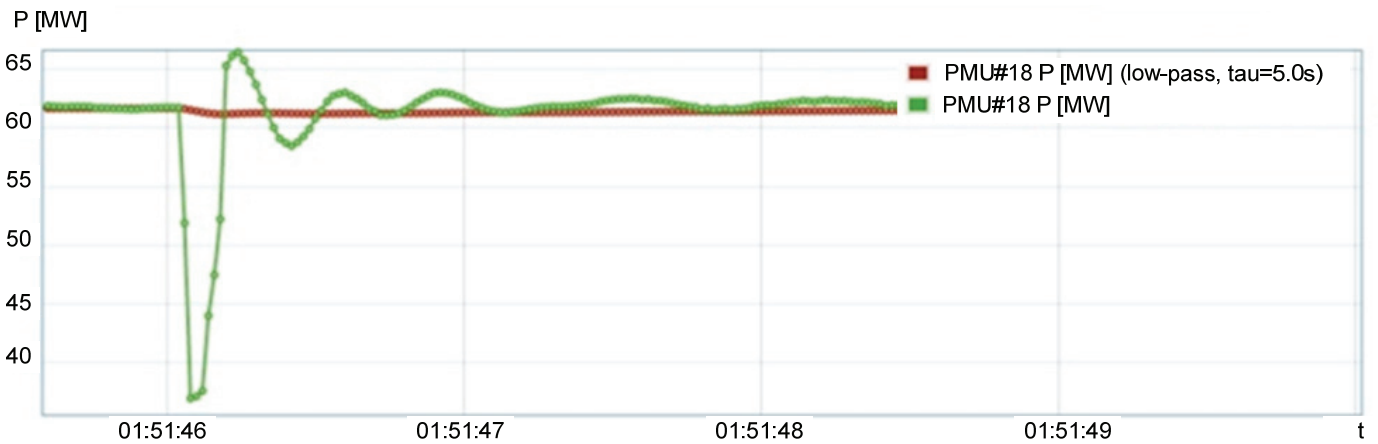

Figure 6 Active power measurements on $24^{\text {th }}$ June 2012

\section{Conclusions}

Real time power swing monitoring based on the synchronized phasor measurements usually refers to the complete power system and inter-area oscillations. This paper offers the solution that focuses on generating facilities. The developed solution for real time power swing monitoring of generators in the actual hydro power plant, based on the synchronized phasor measurements, is presented. The proposed solution will assist the experts from the generation part of power utilities to gain a deeper insight into real time conditions.

Future research is going to focus on techniques for power swing damping in the hydro power plant, regarding disturbances in the rest of the power system. With the reference to SIPS that are intended to maintain the integrity of the power system as a whole, the solution tailored for the specific generating facility presents the localised SIPS - Plant Integrity Protection Scheme (PIPS). Furthermore, the solutions for power swing damping and mitigation of the consequences of disturbances that emerge from the nearby hydro power plants, should be developed. In this way, several local PIPS would be integrated and cooperate under one SIPS.

\section{References}

[1] Schweitzer, E. O.; Whitehead, D. E.; Guzmán, A. Advanced Real-Time Synchrophasor Applications. // Proceedings of the $35^{\text {th }}$ Annual Western Protective Relay Conference / Spokane, 2008, pp. 107-114.

[2] Guzmán, A.; Mynam, V.; Zweigle, G. Backup Transmission Line Protection for Ground Faults and Power Swing Detection Using Synchrophasors. // Proceedings of 
the $10^{\text {th }}$ annual Automation and Integration Seminar at WPDAC / Spokane, 2008.

[3] Blumschein, J.; Yelgin, Y.; Kereit, M. Proper detection and treatment of power swing to reduce the risk of Blackouts. // Proceedings of the Third International Conference on Electric Utility Deregulation and Restructuring and Power Technologies DRPT / Nanjing, 2008, pp. 2440-2446. DOI: 10.1109/DRPT.2008.4523821

[4] Anderson, P. M. Power System Protection. IEEE Press \& McGraw Hill, USA, 1999.

[5] Manual, SIPROTEC. Distance Protection 7SA6. v4.2, Siemens AG, 2000.

[6] Galvan, F. C.; Wells, H. Entergy WAMS Experienced (2004-2008). // Monitoring of Power System Dynamics Performance, Proceedings of the $2^{\text {nd }}$ International Conference / Saint Petersburg, 2008.

[7] Redfern, M. A.; Checksfield, M. J. A Study into a New Solution for the problems experienced with pole slipping protection. // IEEE Transactions on Power Delivery. 13, 2(1998), pp. 394-404. DOI: 10.1109/61.660906

[8] Redfern, M. A.; Checksfield, M. J. A New Pole Slipping Protection Algorithm for Dispersed Storage and Genaration using the Equal Area Criterion. // IEEE Transactions on Power Delivery. 10, 1(1995), pp. 194-202. DOl: 10.1109/61.368398

[9] Clark E. Impedance Seen by Relays During Power Swings with and without Faults. // AIEE Transactions. 64, (1945), pp. 372-384.

[10] Pai, B.; Chaudhuri, B. Robust Control in Power Systems. Springer, USA, 2005.

[11] Kundur, P. Power System Stability and Control.McGrawHill Inc., USA, 1994.

[12] Novosel, D.; Begovic, M.; Madani, V. Shedding Light on Blackouts. // IEEE Power and Energy Magazine. 2, 1(2004), pp. 32-43. DOI: 10.1109/MPAE.2004.1263414

[13] Novosel, D.; Madani, V.; Bhargava, B.; Vu, K.; Cole, J. Dawn of the Synchronization. // IEEE Power and Energy Magazine. 6, 1(2008), pp. 49-60. DOI: 10.1109/MPAE.2008.4412940

[14] Kusljugic, M.; Novosel, D.; Glavic, M.; Pinto, J. A. D. Wide Area Monitoring of Power System Dynamics. // Proceedings of the International Conference on Electrical Engineering / Portugal, 2005.

[15] Ngoma, L. J.; Mazibuko, T. F.; Munda, J. L.; Akumu, A. O. Application of PTP synchronized PMUs in power system small-signal stability analysis. // International Journal of Smart Grid and Clean Energy. 3, 3(2014), pp. 325-333.

\section{Authors' addresses}

Niksa Vrkic, M. Sc.

HEP - Generation Ltd. (HEP - Proizvodnja d.o.o.) Hydropower plants department, Hydro south, PSPP Velebit Ulica grada Vukovara 37, 10000 Zagreb, Croatia E-mail: niksa.vrkic@hep.hr

Srdjan Skok, Ph.D., associate professor University of Rijeka, Faculty of Engineering Department of Electric Power Systems Vukovarska 58, 51000 Rijeka, Croatia E-mail: srdjan.skok@riteh.hr

Vedran Kirincic, Ph.D., assistant professor University of Rijeka, Faculty of Engineering Department of Electric Power Systems Vukovarska 58, 51000 Rijeka, Croatia E-mail: vedran.kirincic@riteh.hr 